\title{
Migration, Identity, and Social Mobility among Iraqis in Egypt
}

\author{
Elisa Pascucci
}

\begin{abstract}
Based on a small-scale qualitative research project with Iraqis living in 6th of October City, one of Cairo's satellite cities, the paper explores the role shifting social identities play in Iraqis' experience of migration and forced displacement. In doing so, it focuses on three major themes emerging from the ethnographic material. First, it discusses the relation between social change in the homeland and other dimensions of Iraqis' belonging, particularly ethnoreligious sectarianism. Secondly, it analyzes the role education and work play in the strategies refugees employ to resist dispossession, as well as in the practices through which other categories of Iraqi migrants rewrite their social identities. Finally, Iraqis' relation with Egyptian society is briefly explored. The findings are discussed in relation to existing literature about social and political change in post2003 Iraq, but also in contemporary Egypt. In doing so, I hope to contribute to re-embed the study of Iraqi migration within the Middle East in its historical and socio-political context, moving beyond policy-driven approaches.
\end{abstract}

\section{Résumé}

Basée sur une recherche qualitative à petite échelle auprès des Irakiens vivant dans la Ville du 6 octobre, une des villes satellites $d u$ Caire, cet article explore le rôle que tiennent les identités sociales changeantes dans l'expérience que font ces Irakiens de la migration et du déplacement forcé. On s'y concentre plus particulièrement sur trois thèmes majeurs ressortant du matériel ethnographique collecté. Premièrement, on examine les relations entre les changements sociaux du pays d'origine et les autres dimensions de l'appartenance irakienne telles que le sectarisme ethno-religieux. Deuxièmement, on y analyse le rôle de l'éducation et du travail dans les stratégies des réfugiés pour éviter l'appauvrissement, ainsi que dans les pratiques employées par d'autres catégories de migrants irakiens pour réécrire leurs identités sociales. Enfin, on y explore brièvement les relations des irakiens avec la société égyptienne. L'auteur met ses observations en relation avec les études effectuées au sujet des changements sociaux et politiques dans l'Irak d'après 2003, mais également avec celles portant sur l'Égypte contemporaine. Cette étude vise enfin à remettre dans son contexte historique et socio-politique l'étude de la migration irakienne au sein du Moyen Orient, tout en dépassant les approches centrées sur les politiques de migration.

\section{Introduction}

Research on Iraqis in Egypt has stemmed from the need to provide policy responses to the refugee flow that invested Iraq's neighbouring countries after the 2003 US-led invasion. The size of the phenomenon has been much smaller in Egypt than elsewhere in the Middle East, yet existing research about Iraqis in the country is mostly emergency and policy driven. Géraldine Chatelard suggests that this approach, based on the paradigm of refugees' visibility, conceals historical continuities in over three decades of migration from Iraq. ${ }^{1}$ Chatelard argues for re-embedding the study of Iraqi migration, looking at the role regional political and social dynamics play in determining this movement of people. ${ }^{2}$ This paper offers a limited contribution to this theoretical re-embedding. Although the size of the study suggests cautions with theoretical generalizations, the findings resonate with some of the insights provided by existing literature on Iraqis in the region. In particular, they highlight the relevance of social mobility in Iraqis' experience of displacement and migration. They point to the importance of understanding how social class intersects 
other dimensions of Iraqis' identity, in particular the ethnoreligious one, and how these influence their prospects for further migration and local integration. Finally, they suggest that social, as well as legal and political dynamics in the host country should not be overlooked when accounting for the experience of Iraqis displaced within the region. This is particularly important when considering the strategies refugees adopt to deal with downward social mobility in a protracted refugee situation. ${ }^{3}$

\section{Iraqi Migration to Egypt}

Although a signatory of the 1951 Geneva Convention, Egypt does not have a national asylum law. Kagan defines the legal framework for refugee protection in the country as "regrettably confusing," highlighting three major factors which contribute to this uncertainty. ${ }^{4}$ First, implementation of refugee and migration policies in the country has often been the result of arbitrary governmental choices rather than of the application of international laws. Secondly, Egypt has introduced important reservations to the 1951 refugee convention, limiting refugees' access to economic and social rights. Finally, refugee rights have been further limited by the signature of the 1954 Memorandum of Understanding (MOU) with the United Nations High Commissioner for Refugees (UNHCR). A result of the MOU is that determination of refugee status is carried out by UNHCR exclusively. Upon obtaining refugee documentation from UNHCR (yellow cards for asylum seekers and blue cards for recognized refugees), refugees are expected to report their cases to the Ministry of Foreign Affairs. The latter subsequently asks the Ministry of the Interior to issue a six-month residence permit. However, Iraqi refugees who arrived in the country after 2003 have been considered as prima facie refugees and did not go through individual refugee status determination. ${ }^{5}$ The policy adopted by UNHCR results from a "favorable presumption" about the legal validity of Iraqis' claims, and significantly improved their living conditions. ${ }^{6}$ However, generalized access to refugee status might also have contributed to hide the complex interplay of economic, social, and historical factors that determine this migration. As will be shown below, not all Iraqis in Egypt consider themselves to be refugees. Some of them have access to residence permits as investors or students, and choose not to apply for refugee status. However, migration patterns are complex and mixed migration common. ${ }^{7}$ Moreover, self-perceptions and attitudes towards refugee status often shift over time. A brief analysis of available figures confirms this complexity. According to entry data, between 100,000 and 150,000 Iraqis would have settled in the country, mainly between 2006 and 2008, when the Egyptian government put a halt to the issue of entry visas. ${ }^{8}$ In $2008,10,000$ Iraqis were in possession of UNHCR documentation, while at the end of 2009 there were only 6,572 registered refugees. This points to the high mobility of Iraqis in Egypt, among whom selfrepatriation and resettlement are deemed to be common. In 2010, however, numbers grew again. In 2011, 7,157 Iraqi refugees were reported to be registered with UNHCR. ${ }^{9}$ It is likely that many Iraqis avoided registration in the first years of residence in Egypt, perceiving their migration as temporary, and turned to UNHCR at a later time, when both prospects for return and private financial resources deteriorated.

Most Iraqis settled in the Egyptian capital-particularly in the areas of 6th of October City and Madinet Nasr-and, to a lesser extent, in Alexandria. Between 2006 and 2008 they rapidly became the second-largest national group among Egypt's immigrant population, after Sudanese. ${ }^{10}$ As a consequence, local and international non-governmental organizations (NGOs) working as UNHCR implementing partners put in place services which targeted Iraqis exclusively. Predominant narratives among practitioners describe Iraqis as a cluster of refugees whose demands are particularly difficult to respond to. As the manager of an international charity remarked, "Over 70 percent of the Iraqi families we work with suffer from anxiety disorder and would benefit from some sort of psychological counseling." 11 She added that the causes of this anxiety were rather difficult to understand, as their living conditions generally were better than those of other refugee groups. Interviews with other NGO workers confirm this perception. Concerns about the deterioration of their social and financial status, linked to lack of legal access to work and public services, are reportedly one of the main reasons why Iraqis perceive themselves as vulnerable. Middle-class anxieties about children's education and standards of living characterize Iraqi refugees in the narratives of most humanitarian practitioners in Egypt. However, it should be noted how the majority of them do not belong to Iraq's wealthiest social strata. The post-2003 Iraqi displacement is deemed to have taken place in three major waves. ${ }^{12}$ Former regime elites and uppermiddle-class professionals and intellectuals would have fled between 2003 and 2005, while most Iraqis in Egypt left their country after the outbreak of sectarian violence which followed the 2006 Samarra bombings. This third migratory movement is deemed to have been the largest, involving people from different ethno-sectarian and social backgrounds. ${ }^{13}$ The encounters I had with Iraqis in Cairo's 6 th of October City confirm this picture of socio-cultural and religious diversity. Although the majority of the people included in this study were Arabs and Sunni Muslims-reflecting the overall ethno-religious composition of the Iraqi population in Egypt ${ }^{14}$ - a minority of Shiites and a small number of Christian families were resident in the neighbourhood 
when the study was conducted. Some of the Iraqis I met had chosen Egypt as a destination for its relatively low living costs, as well as for the availability of resettlement programs. ${ }^{15}$ They had therefore applied for refugee status and sought humanitarian assistance since their arrival in the country. Others, however, had moved to Egypt counting on a significant amount of private savings, which they had been able to invest in entrepreneurial activities-from small grocery shops to factories and import-export companies. The ethnographic accounts examined below help to shed light on the relationship between these two different categories of migrants. More importantly, they suggest that class perceptions and performances, influenced by Iraqi refugees contacts with the hosting society, can be productively studied in their dialectic relation with other dimensions of Iraqis' identities. The findings are therefore discussed in the light of historical and theoretical considerations on the socioeconomic background of the Iraqi displacement, as well as on the Egyptian social and urban context.

\section{Methods and Research Location}

The paper is based on ethnographic research with Iraqi migrants living in 6th of October City, one of Cairo's satellite cities, carried out for a period of about four months. During it, I was hosted by a family of refugees from Baghdad, living in 6th of October City's 7th District, whom I met teaching English as a volunteer to their youngest son. The family members helped me to snowball among their contacts, friends, and neighbours. Volunteer work provided me with opportunities to recruit other participants, diversifying my contacts. In total, I conducted participant observation with three different family units, in addition to in-depth, unstructured interviews with 20 individuals from different social backgrounds. I also interviewed practitioners from six different NGOs working on refugee assistance.

The majority of my Iraqi informants were from Baghdad. Only three of them were originally from other districts in central and southern Iraq. However, all had close relatives living in the capital, or had lived there themselves for study or work. As already remarked, all the participants, with the exception of one family of Christians, were Arabs and Sunni Muslims, reflecting the ethno-religious composition of the larger population. As a female researcher, building a rapport with women was generally easier for me. However, men are slightly more represented among my informants. Shifting gender relations in Iraqis' experience of migration are briefly analyzed in the discussion of the findings. However, an in-depth account of the relation between gender, migration, and social mobility in the case of Iraqis in Egypt would require a theoretical and empirical engagement that exceeds the scope of this paper. Knowing Modern
Standard Arabic and colloquial Egyptian, and working with people who generally had a relatively good command of English, in most cases I was able to conduct the interviews by myself. In some others I needed assistance with translation of recorded material from Iraqi Arabic into English.

The choice of 6th of October City as a research location was dictated by its being a well-known local hub for Iraqi migrants. Built at the beginning of the 1980s as a result of plans for industrial development in the Giza desert plateau, ${ }^{16}$ about 30 kilometres northwest of the Egyptian capital, 6th of October hosts around one million residents. While workers employed in factories and low-skilled service jobs can be found living in its outskirts, many Egyptians who moved there in the 1980s and 1990s were nouveaux riches. Alongside industrial sites and middle-class residential areas, gated communities, Saudi-owned shopping malls, and international hotels mark the local landscape. As several other suburbs and new towns, 6th of October can be regarded as a product of urban and social change in neoliberal Egypt, characterized as it is by spatialized markers of social stratification and defensive home ownership. ${ }^{17}$ Moreover, the place offers insights about the role of international migration in these processes. Egyptian returnees from Europe and the Gulf, who invested their remittances in remunerative commercial activities, traditionally constitute a significant part of 6th of October City's new rich. Since the late 1990s, foreign investors from Turkey, United Arab Emirates, and central Asia, as well as students from Saudi Arabia, Qatar, and other Gulf states, have joined this emerging bourgeoisie, making of 6th of October an interesting example of regional cosmopolitanism. In it, Iraqis are one of the most recently settled, yet by far the largest, national group. In the 7th District, the area of 6th of October City where the UNHCR office is located and the concentration of Iraqis is higher, their presence is rather visible. Although this visibility is reported to have decreased since 2008, due to repatriation and resettlement, Iraqi ethnic stores, coffee shops, and bakeries are still present. The landscape evokes a sense of cohesion and diasporic national belonging which is difficult to find in Iraqis' narratives. The following section explores the dynamics of and reasons for this lack of sense of community among the Iraqis I have worked with. In doing so, I raise some questions on the relationship between ethno-religious identity and economic and social change in contemporary Iraq, as reflected in the Iraqi diaspora.

\section{Ethno-religious Sectarianism, Social Change, and Displacement in Post-2003 Iraq}

Sectarianism and sectarian violence are the dominating paradigm in media representations of the Iraqi conflict and displacement. Similarly, in the interviews I conducted 
among humanitarian practitioners, community networks among Iraqi refugees are often described as fragmented along ethnic and religious lines. Overall, my participant observation can not be said to contradict these perceptions. It rather confirms the existence of what a humanitarian worker defined as "an all-permeating feeling of mistrust" that would prevent Iraqis in Cairo from developing a binding sense of community. ${ }^{18}$ However, some questions about the nature and roots of these divisions can be raised. The Iraqis I met did mention ethnic and religious differences when discussing their problems in Iraq and Egypt, yet they generally attributed only relative importance to them. This is probably due to the fact that, in their neighbourhood in Cairo, they found themselves in a rather homogenous environment, in which Arab Sunni Muslims are the prevalent group among both locals and immigrants. Nevertheless, some of the interviews also resonate with existing literature that problematizes the category of religious and ethnic sectarianism in contemporary Iraq. Moreover, they point to the role social stratification plays in causing divisions among Iraqi refugees.

Sarah, ${ }^{19}$ a single woman in her late 20 s from Baghdad's affluent neighbourhood of Hay al Jamaa, provides an interesting example. She was the youngest daughter of a retired engineer employed in the public sector, living with her family in the 7th District. They arrived in Egypt in 2007 and applied for asylum a few months afterwards. Although they did not feel totally comfortable using the term, all members of the family defined themselves as refugees and hoped for resettlement to Canada or the United States through UNHCR. When asked about her relationship with her Iraqi neighbours in Egypt, Sarah explained:

... If they visit, it is just for courtesy, a social duty. It's false courtesy. We don't trust each other and I don't like to hang out with them. There are jealousy and envy. People envy your apartment if bigger than theirs, are jealous if you can pay for better private education for your children. The fact is, you know, Iraq changed. It is not the country it used to be and people have a narrower mind. They would do anything for money. And if you need a job, you need to have relations, to be affiliated to a political party. To be safe, you need the private militias of the party, of the religious group. If you don't belong to these groups, you have to leave. ${ }^{20}$

Solidarity and mutual help, often explained as resulting from Islamic moral obligations, are present among Iraqis in 6 th of October City. It is not uncommon to find groups of university students organizing themselves to help widows living alone in Egypt, or to collect money to be donated to Egyptian orphanages and charitable institutions. Nevertheless, narratives like Sarah's are common. Solidarity and compassion are undermined by feelings of mistrust, suspicion, and envy. These latter are significant to the extent that they often determine choices about where to live, or where to seek financial or humanitarian help. Two of the families included in the study reported avoiding contacts with NGOs employing Iraqis living in their neighbourhood as community facilitators. They did not trust their behaviour and, they said, their sources of revenue were "unclear." It is likely that the decision to avoid contacts with specific organizations prevented them from receiving proper legal assistance, jeopardizing their application for resettlement.

As in Sarah's quote, envy often results from competition over symbols of social status such as the size of one's house and access to expensive private education or lack of it. Among the Iraqis I have worked with, this preoccupation with social status and "appearance" was often reported to have been a characteristic of Iraqi middle-class culture since the sanctions era (1991-2003), a perception which finds an echo in historiographies of contemporary Iraq. ${ }^{21}$ In line with Saddam Hussein's nationalistic propaganda, what many Iraqis define as "a culture of pride and dignity"22, was then aimed at concealing the harsh process of impoverishment the country was undergoing. However, those who, like Sarah, belonged to middle-class families of former stateemployed professionals tended to consider competition over economic status as a new phenomenon that had appeared after the war. In their narratives sectarian divisions, moral corruption, and rampant social stratification are strictly intertwined.

Existing literature describes this intermingling of economic liberalization, dismantling of state apparatuses, and institutionalized sectarianism in contemporary Iraq. ${ }^{23}$ Similar phenomena have also been observed in other countries in the region. For Fawaz, clientelism and religious sectarianism are the form the "entrenchment of market mechanisms into daily activities" has taken in post-civil war Lebanon. ${ }^{24}$ In the case of Iraq, Al Tikriti calls for a more careful consideration of the relation between ethno-religious divisions and policy choices in the aftermath of war. While Iraqi ethnic, religious, and tribal identities have deep historical roots and were institutionalized under Ottoman rule, sectarian violence only broke out in specific moments throughout the country's history. ${ }^{25}$ After 2003, policies aimed at dismantling the army and the state bureaucracy had the effect of depriving Iraq of secular institutions. Violence targeting the educated urban middle classes caused massive internal and international displacement among upper social strata. This led to the destruction of the pre-existing social organization in which, as Al Tikriti contends, affiliation to political parties and secularized social identities prevailed over religious sectarianism, at least in 
urban contexts. ${ }^{26}$ In the meantime, policies aimed at creating a new social and economic model were enforced. ${ }^{27}$ The provision of basic social and infrastructural services was delegated to non-state actors, leading to increasing political prominence of religious organizations. The urban geographies of Iraq were rearranged around ethno-religious segregation, and allegiances to religious parties and militias became a constitutive element of the social fabric. ${ }^{28}$ For some Iraqis I met in Egypt, the decision to leave the country was linked to their lack of integration in these new social networks. This was reported to imply not only vulnerability to violence, but also, as Sarah remarked, exclusion from the most profitable sectors of the job market.

Economic reasons are often important in Iraqis' decision to leave their country. ${ }^{29}$ After the war, the implementation of neo-liberal economic policies failed in improving employment rates. ${ }^{30}$ For large sections of the urban middle classes, this added economic precariousness to what has been defined as Iraq's "generalized environment of insecurity." 31 Economic policies are an important part of the social and institutional restructuring of Iraq. After Paul Bremer's Coalition Provisional Authority terminated its mandate in June 2004, power was handed over to the newly formed local government under condition of total adherence to the neo-liberal doctrine. ${ }^{32}$ This was "aimed at eliminating all vestiges of the Iraqi centrally planned economy $(\ldots)$ Assets, and indeed the mechanisms of economic governance, were transferred from the public sector to private actors." 33 The new policy included a rapid transition from state-led development to privatizations, dismantlement of large portions of the public sector, market deregulation, and creation of an export-oriented economy. Large-scale plans for economic liberalization, particularly in the agrarian sector, had been promoted by Saddam Hussein's government already in the early 1980s. The effects on working and lower-middle classes had been significant, causing waves of political unrest, internal displacement, and international migration. ${ }^{34}$ However, this had been essentially a state-led process, which had preserved state bureaucracy as a source of employment. This process of economic infitah (opening) had been interrupted by the imposition of economic sanctions after the 1991 Gulf War, which condemned the country to international isolation. ${ }^{35}$ It was thus only after the war started in 2003 that a radical plan of economic neoliberalization was promoted.

Refugees in Cairo often point to the intertwining of economic privatization, sectarianism, and clientelism in explaining lack of security and social cohesion in contemporary Iraq. This concise historical overview helps to shed light on the complex roots of this perception. The ethno-religious homogeneity which characterizes Iraqis in Cairo does not allow drawing conclusions on the role of sectarianism among Iraqis in general. However, it should also be noted how the interactions observed between the one Christian family I met and their Muslim neighbours were devoid of tensions. None of the members of the family reported having suffered religious discrimination among their national community. Similarly, tensions and conflicts between the Sunni majority and the small number of Shiite refugees living in Cairo were rare. Shiites were rather reported to suffer discrimination by the Egyptian authorities. In 2006, these latter rejected a request to open a Shiite mosque in 6 th of October. ${ }^{36}$ The episode caused discontent, protests, and fears that Iraqi Shiites may face deportation, and it can be regarded as another example of the role policies play in shaping interreligious interactions, both in the country of origin and in the hosting society.

Overall, both existing literature and ethnographic material suggest caution in attributing lack of community cohesion among Iraqi refugees to religious and ethnic cleavages only. As already remarked, not all the people who left Iraq for Egypt consider themselves as victims of dispossession and lack of social networks, or identify themselves as refugees. Differences between them and refugees often revolve around social and economic status. However, as the next section will show, for both groups reasons to migrate are mixed. Moreover, relations between them are marked by ambivalence, oscillating between resentment caused by real and perceived inequalities and feelings of solidarity resulting from shared national belonging.

\section{Mixed Migration and Iraqi Transnational Economic Migrants}

A category of Iraqis living in 6th of October City can be considered as transnational migrants who profited from the economic liberalization Iraq underwent after 2003. The volume of trade between Egypt and Iraq is reported to have grown significantly between 2005 and 2010. According to official statistics, in 2009, 3,196 Iraqi companies were operating in Egypt, amounting to 15 percent of total Iraqi foreign investment. ${ }^{37}$ The relation between these transnational economic activities and Iraqi displacement to Egypt is confirmed by a statement made by Mahmoud Mohieddin, the former Egyptian Minister of Investment. During the first joint Iraqi-Egyptian investment convention, held in Baghdad in August 2009, Mohieddin is reported to have commented on the high number of Iraqi enterprises in Egypt, expressing his hope that "those companies will return to Iraq when they have the opportunity. We are following closely what is happening in Iraq." 38 Iraqi migrants engaging in commercial and entrepreneurial activities between the two countries were able to find work and life opportunities in Cairo's 
upscale new towns and residential compounds. As foreign investors in Egypt, they enjoy a privileged visa regime, and do not identify themselves as refugees. On the contrary, they tend to underline their difference through narratives emphasizing their entrepreneurial success and wealthy lifestyle. However, many Iraqi entrepreneurs I met in Cairo do mention political instability and serious safety concerns as reasons for not permanently residing in Iraq or sending their families to live abroad.

Wissam, a man in his late 30s, owned a factory in Upper Egypt but lived with his wife and two children in 6th of October City. When I met him, he ostentatiously showed the signs of his economic fortune through branded clothes and electronic gadgets.

I am very happy in Egypt. I earn good money, my wife is happy, she can relax, go out, she can afford going to the gym. My situation is completely different from refugees and I never had any contacts with the United Nations.

Yet, as our conversation went on, Wissam disclosed how his reasons to live abroad were also related to Iraq's lack of stability and security.

I don't care about Iraq, about what happens there. I only go for work, for commercial reasons, do what I have to do and come back I don't bring my family because it is very dangerous, unlivable, especially for women. I don't care about what happens there. ${ }^{39}$

The case of Iraqis in 6th of October City points to the growing relevance of mixed migration in understanding the Iraqi displacement. ${ }^{40}$ Economic concerns and fears of persecution and generalized violence are often intertwined in individual reasons to leave the country. Moreover, Iraqi refugees and migrants in Cairo live in proximity and have close economic, social, and personal relations. My first meeting with Wissam took place in an Iraqi café called Shatt el-Arab, a popular place in the 7th District. Named after the region spanning southeast Iraq and southwest Iran where mostly Sabeans live, it was attended exclusively by Iraqi men to drink tea and smoke shisha. The coffee shop appeared to be a rather socially mixed space, an interesting exception in Cairo's strict spatial segregation along class lines. Wissam's social life took place mostly in that coffee shop, hanging out with his countrymen. Some of them were very good friends of his. Others were rather acquaintances who seemed uneasy before his physical and verbal exhibition of richness. However, the socially mixed nature of the coffee shop was largely reflected in Wissam's group of friends. Their case exemplifies the complex social and economic relations between Iraqis who self-identify as refugees and wealthier migrants with different legal status. Solidarity and sense of national belonging coexist with inequalities and conflicts. Although many among his friends were significantly less rich than him, Wissam was bound to them by respect and esteem. They were, he explained, from honoured families with a high educational level and used to have very good professional positions. Wissam appeared to be aware of his status of nouveau riche. His relation to his Iraqi neighbours and friends appeared marked by dual feelings. On the one hand he was proud of having been able, unlike many of his fellow citizens in Egypt, to profit from the good opportunities provided by Iraq's and Egypt's neo-liberal economies. On the other, he expressed a sense of solidarity, respect, and even sorrow for people whose cultural capital and respectability used to be somehow superior to his own, but who were facing financial difficulties in Egypt.

As Wissam, Samira, the 22-year old daughter of a wealthy Baghdadi family, was excited about the economic success of her family and happy with her life in Egypt. Yet when I met her for the first time she also expressed concern about the trip to Baghdad her family was planning for the end of the year. During a recent visit, a bomb had blasted near her parents' car while they were driving in central Baghdad. The episode had been very shocking for the whole family. It epitomized the lack of security that still affected their country, and reminded them of the violent destruction they had to flee from. Similar stories, and the associated feelings of anxiety, are common among the richest Iraqis living in Egypt who travel to their home country on a regular basis. Drawing a sharp line between the successful stories of people like Wissam and Samira, and the painful experience of disempowerment of refugees who have been hit by processes of dispossession would be inaccurate. Among the Iraqis I came to know in 6th of October, experiences of violence and loss are common to individuals of all social backgrounds and economic statuses. Moreover, national belonging is one of the most relevant lines along which social interactions are organized in the rather international environment of 6 th of October. However, it often conceals a number of unexpressed conflicts and divisions around social status, in which some individuals and households are left to struggle against impoverishment, often without a reliable network of support.

\section{Education, Work, and Social Mobility: The Egyptian Context}

The Iraqi refugees I met in Cairo adopted several strategies to resist downward social mobility, although rarely did they prove to be successful. In this regard, the story of Sarah's family is paradigmatic. When I met Sarah, her parents had run out of savings trying to support themselves in Egypt. 
The only two sources of income her father had left were the small pension that, like many other Iraqis in Cairo, he received from Iraq every month, and a similarly small amount of money coming from letting his house in Baghdad. The house was let to a friend for less than the actual market price. This was because, as many Iraqis explained, till 2008 houses let to strangers were often looted, or occupied by religious militias who forced people to move in planned operations of ethno-religious segregation. Letting to relatives and close friends was therefore the only way they had to be sure to have their property back. For Sarah's parents, the two sources of revenues together covered the basic needs of their six children. The parents appeared to be torn between desire to return, which explained their decision not to sell the house, and hope for a better future for their children through resettlement to a Western country. They had done their best to guarantee them the same standard of living they used to have in Iraq, where they could afford a car and spending their holidays abroad. Sarah explained that her father had spent more than $\$ 10,000$ US in just one year to allow her younger brother to study in one of the many expensive private universities of 6th of October City, attended mostly by foreign students coming from the Gulf region. When the father realized that the debt he was accumulating was too severe, her brother was forced to interrupt his studies, and as a result, according to Sarah, he was drowning in a state of depression.

Education is central in the strategies Iraqis adopt to preserve their social status. Private schools and universities are often the only option available for Iraqis in Egypt, where refugees face restrictions in enrolling their children in public education. ${ }^{41}$ However, many Iraqi families I spoke to affirmed that, even if they were allowed to, they would not send their children to Egyptian public schools. The quality of the education these provide was perceived as extremely poor, especially in foreign languages and technical and scientific subjects. The idea-widespread among middle-class Egyptians - that public schools are for the children of the poor and the uneducated seemed to prevail. It is arguable that the choice of expensive private education is for Iraqis in Egypt a "reconversion strategy." Bourdieu defines this as "the set of outwardly very different practices whereby individuals or families tend, unconsciously or consciously, to maintain or increase their assets and consequently to maintain or improve their position in the class structure." ${ }^{2}$ As in Bourdieu's description, the aim of conserving or improving the family's social position is often pursued by exchanging one form of capital with another. Investing financial capital into education is fundamental for middle-class Iraqis. ${ }^{43}$ This seems to apply both to those hoping to preserve a cultural capital threatened by impoverishment, and to the new rich attempting to acquire new middle-class legitimacy.

However, for families of refugees like Sarah's, these attempts are often difficult to sustain. Also in this, their experience mirrors that of local educated urban middle classes. The Egyptian market for private education is fastgrowing and increasingly expensive. Only people with remunerative entrepreneurial careers or employed in the upscale, internationally oriented sectors of the job market are able to afford the kind of investment in education which guarantees to their children access to good employment opportunities. ${ }^{44}$ This process of social stratification invests Iraqi refugees in Cairo. Access to private education also corresponds to inclusion in circuits of globalized belonging and upscale consumption cultures. ${ }^{45}$ In one of our meetings, Samira and I had a conversation which helps to illustrate this aspect. Her father, she explained, ran a successful business which allowed her and her brothers to study in private technical faculties. Alongside her major in pharmacy, Samira took private lessons in English and informatics.

English is essential nowadays, for any job you want to do, in Iraq, Egypt, in any other Arab country. And I love speaking English, and have many European friends that I meet every time I go to Sharm El Sheykh, about twice or three times a year. ${ }^{46}$

Samira's case is also an interesting example of how migration provides wealthy Iraqi women in Egypt with increased opportunities to study, work, and engage in social and recreational activities outside of the space of the home. Like her, some of the women I met attributed this to the absence of gender and sectarian violence in Egypt, generally perceived as a safe country. However, this feeling was altered by the uprising started in January 2011, which pushed a significant number of families to temporarily leave the country. Shifts in gender relations also affect families of refugees with lower social status. In the cases I had the chance to observe, these changes are often linked to policies of humanitarian assistance. Services in Egypt are often designed around a "femininized" refugee subject, conceived as being in a position of need and passivity. ${ }^{47}$ As a result, women are often privileged interlocutors in the relation with humanitarian agencies. This has ambivalent and potentially negative effects. On the one hand, it seems to increase their power within families. On the other, it contributes to further relegate women who are often well-educated and with successful working histories in the homeland to the exclusive role of caregivers. The relation between gender, refugee condition, and social mobility among Iraqis in Egypt can not be thoroughly explored here, and would deserve further research. 
As access to private education and related spaces of socialization become increasingly exclusive, a category of young Iraqis in Cairo struggle to find other venues of local inclusion. For those who have no other option to support themselves, access to the lower sectors of the job market is mediated through networks of national solidarity. The restrictions Egypt applies to the 1951 convention exclude refugees from access to regular employment. As a result, some of them rely on informal, casual jobs in small ethnic businesses such as coffee shops and restaurants, but also in factories. Access to these networks of employment is also gendered. Social and parental control often prevents young women from accepting jobs which are deemed to be degrading, or not adequate to their qualifications and social status. However, some of the young women I met were employed as secretaries or shopping assistants in local Iraqi and Egyptian businesses.

Hamed was a young man with a degree in engineering. He had arrived in Egypt in 2006 with his parents and brothers, all registered with UNHCR. His work experience in a big supermarket owned by an Iraqi entrepreneur was recalled as frustrating.

In the supermarket, he [the employer] used to exploit me. Still, he used to exploit Egyptians much more than me. I got a better treatment cause I was Iraqi. With me, he would pay me more, EGP 800 [\$135] per month, while Egyptians would earn 600 per month. Still, it was ridiculous. 12 hours per day, every single day, from 2 or $3 \mathrm{pm}$ to $3 \mathrm{am}$, no holiday at all. No Aid, no Friday, no Sunday, nothing at all. If I sick, I don't get paid. [ ... ] I had that life for one year. Then, Ousama [his brother] and me decided to share, for the boss was OK. We would share and work 6 hours each, everyday, no holidays as I told you, for EGP 800 per month. ${ }^{48}$

Hamed's narrative is interesting for at least three reasons. First of all it provides another example of the ambiguities that characterize the relationship between refugees and wealthy Iraqi migrants. While he had been able to find a job thanks to networks within his national community, the working conditions had proved to be rather exploitative. Secondly, it offers interesting insights on labour conditions in Egypt and how they affect the less wealthy among young Iraqi refugees. Hamed describes the job environment in factories, supermarkets, and shopping malls in 6th of October City as mixed: "You find Egyptians, Africans and sometimes Iraqis, but only those who have less money." According to him, foreign workers in the supermarket were employed informally, but many Egyptians had no regular contracts either. Finally, Hamed's experience sheds light on the mutual perceptions which shape the relation between Iraqis and locals. Egyptians, Hamed explained, are paid less because they are deemed to be poor and, unlike Iraqis, used to low-skilled jobs in dirty and unsafe environments. These impressions mirror local perceptions of Iraqi migrants. In 6th of October, Madinet Nasr, Heliopolis, and Rehab, all middle-class areas of Cairo where Iraqi families have settled, Egyptians commonly consider Iraqis as wealthy and successful intruders. Their affluence is often blamed for rising estate prices. In this regard, it is important to remember how the booming Iraqi oil economy of the 1970s saw the immigration of millions of Egyptians, employed in the extractive and industrial sectors. ${ }^{49}$ Mutual perceptions of richness and poverty are largely shaped by this shared migration history. According to the practitioners I talked to, Egyptian stereotypes of Iraqis would be a result of the generalized lack of knowledge about refugee problems and rights. However, they also reflect the complex, mixed nature of Iraqi migration to Egypt, as well as the local processes of social stratification it intersects.

\section{Conclusions}

The policy categories imposed on the Iraqi displacement conceal differences between refugee flows and other forms of migration. People lacking social and financial capital are forced to flee Iraq and rely on assistance to find durable solutions to displacement. However, others have the assets to successfully engage in forms of transnational mobility and economic activity. ${ }^{50}$ An approach which re-embeds the study of the Iraqi displacement in its socio-historical context helps to grasp differences and continuities between these different kinds of migration. In the case here analyzed, mixed motivation and frequent economic and social relations between these two categories of migrants does not allow drawing sharp distinctions. However, feelings of inequalities and tensions are common among Iraqis in Cairo. These often revolve around changes in social status caused by displacement and post-conflict policies in the homeland. Existing literature confirms that these new social mobilities deserve further attention, and that their relation with ethno-religious sectarianism should be problematized. Finally, the paper has offered insights on how social stratification in Egypt influences the experience of Iraqi residents in the country. A re-embedded approach to the study of Iraqi migration in the region cannot but benefit from a thorough analysis of socio-economic change in hosting societies.

\section{Notes}

1. Géraldine Chatelard, "What Visibility Conceals: Reembedding Refugee Migration from Iraq," in Dispossession and Displacement: Forced Migration in the Middle East and 
Africa, ed. Dawn Chatty and Bill Finlayson (New York and Oxford: Oxford University Press, 2010), 17- 44.

2. Ibid., 44.

3. Cf. Jeff Crisp, Refugee Protection in Regions of Origin: Potential and Challenges, 2003, accessed March 6, 2012, http://www.migrationinformation.org/Feature/display .cfm?id11/4182.

4. Michael Kagan, Shared Responsibility in a New Egypt: A Strategy for Refugee Protection (The American University in Cairo, School of Global Affairs and Public Policy, Centre for Migration and Refugee Studies, September 2011), 11, accessed March 6, 2012, http://www.aucegypt.edu/GAPP/ cmrs/Documents/KaganRefugeePolicyEgypt1109.pdf.

5. Ibid., 11.

6. Ibid., 13 .

7. Cf. Chatelard, "What Visibility Conceals"; and Nicholas Van Hear, Rebecca Brubaker, and Bessa Thais, "Managing Mobility for Human Development: The Growing Salience of Mixed Migration" [United Nations Development Programme (UNDP), Human Development Reports, Research Paper, April 2009], accessed March 6, 2012, http://hdr.undp .org/en/reports/global/hdr2009/papers/HDRP_2009_20 .pdf.

8. Philippe Fargues et al., Iraqis in Egypt: A Statistical Survey in 2008 (Cairo: The American University in Cairo, Center for Migration and Refugee Studies, 2008), accessed March 6, 2011, http://www.aucegypt.edu/GAPP/cmrs/Documents/ Iraqis\%20in\%20Egypt\%20Provisional\%20Copy.pdf.

9. United Nations High Commissioner for Refugees (UNHCR), Egypt Fact Sheet, June 2011, accessed July 17, 2011, http://www.unhcr.org/4e1412df9.html.

10. Ibid., 1 .

11. Interview, Cairo, March 2011.

12. Nabil Al Tikriti, "There Go the Neighbourhoods: Policy Effects vis-à-vis Iraqi Forced Migration," in Dispossession and Displacement: Forced Migration in the Middle East and Africa, ed. Dawn Chatty and Bill Finlayson (New York and Oxford: Oxford University Press, 2010), 249-72.

13. Ibid., 268.

14. Fargues et al., Iraqis in Egypt, 39.

15. Emily Minnick and Noheier Nashaat, "Stuck" in Egypt: Iraqi Refugees' Perceptions of Their Prospects for Resettlement to Third Countries and Return to Iraq (Cairo: The American University in Cairo, Centre for Migration and Refugee Studies In-depth Analyses, 2009), accessed March 10, 2011, http://www.aucegypt.edu/GAPP/cmrs/reports/ Documents/CMRS_Reporton_Return_and_Resettlement_ For_Web.pdf.

16. Dona J. Stewart, "Cities in the Desert: The Egyptian NewTown Program," Annals of the Association of American Geographers 86, no. 3 (1996): 459-80.

17. Cf. Diane Singerman and Paul Amar, Cairo Cosmopolitan: Politics, Culture and Space in the New Middle East (Cairo: The American University in Cairo Press, 2006).

18. Interview, Cairo, March 2011.
19. All the participants' names have been changed in order to protect confidentiality.

20. Interview, Cairo, April 2011.

21. Thabit A. J. Abdullah, Dictatorship, Imperialism and Chaos: Iraq since 1989, (Halifax: Fernwood Publishing, 2006), 71-81.

22. Interview, Cairo, April 2011.

23. Samer Abboud, "Failures (and Successes?) of Neoliberal Economic Policies in Iraq," Journal of Contemporary Iraqi Studies 2, no. 3 (2008): 425-42; and Al Tikriti, “There Go the Neighbourhoods," 249-72; cf. also David Harvey, The New Imperialism (New York: Oxford University Press, 2003).

24. Mona Fawaz, "Neoliberal Urbanity and the Right to the City: A View from Beirut's Periphery," Development and Change 40, no. 5 (2009): 827-52, 839.

25. Al Tikriti, “There Go the Neighbourhoods," 249.

26. Ibid., 258.

27. Abboud, "Failures (and Successes)?," 426.

28. Al Tikriti, "There Go the Neighbourhoods," 269.

29. Chatelard, "What Visibility Conceals," 19; and Philippe Marfleet, "Iraq's Refugees: 'Exit' from the State," International Journal of Contemporary Iraqi Studies 1, no. 3 (2007): 397-419.

30. Abboud, "Failures (and Successes)?," 430; and Chatelard, "What Visibility Conceals," 19.

31. Ibrahim Sirkeci, "War in Iraq: Environment of Insecurity and International Migration," International Migration 43, no. 4 (2005): 197-214.

32. David Harvey, "Neoliberalism and the City", Studies in Social Justice 1, no. 1 (2007): 5-6.

33. Abboud, "Failures (and Successes?)," 426.

34. Robert Springborg, "Infitah, Agrarian Transformation, and Elite Consolidation in Contemporary Iraq," The Middle East Journal 40, no. 1 (1986): 33-52; and Abdullah, Dictatorship, Imperialism and Chaos, 52-53.

35. Abdullah, Dictatorship, Imperialism and Chaos, 52-53.

36. Associated Press, "Iraqi Refugees Protest Restrictions Imposed by Egypt," April 12, 2006, accessed March 6, 2012, http://www1.whdh.com/news/articles/world/MI34260/.

37. "Memorandum of Understanding on Economic Cooperation Between Egypt and Iraq," Iraqi Updates, 16 August 2009, accessed March 10, 2012, http://admin.iraqupdates .net/p_articles.php/article/56975.

38. “Memorandum of Understanding," 16 August 2009.

39. Interview, Cairo, March 2011.

40. Géraldine Chatelard, "Iraqi Refugees: Making the Urban Approach Context-Specific," Humanitarian Exchange 51 (2011): 9-11.

41. Minnick and Nashaat, Stuck in Egypt, 8.

42. Pierre Bourdieu, Distinction: A Social Critique of the Judgment of Taste (London: Routledge and Kegan Paul, 1988), 125.

43. Pierre Bourdieu, Distinction, and "The Forms of Capital", in Handbook of Theory and Research for the Sociology of 
Education, ed. J. G. Richardson (New York: Greenwood Press, 1986), 241-58.

44. Anouk de Koning, Global Dreams: Class, Gender and Public Space in Cosmopolitan Cairo, (Cairo: The American University in Cairo Press, 2009).

45. Ibid., 65-93.

46. Fieldnotes, Cairo, March 2011.

47. Cf. Jennifer Hyndman and Wenona Giles, "Waiting for What? The Femininization of Asylum in Protracted Refugee Situations," Gender, Place and Culture 18, no. 3 (2011): 361-79.

48. Interview, Cairo, April 2011.

49. Abdullah, Dictatorship, Imperialism and Chaos, 53.

50. Chatelard, "What Visibility Conceals," 21.

Elisa Pascucci is a DPhil candidate at the School of Global Studies, University of Sussex, and research fellow at the American University in Cairo's Centre for Migration and Refugee Studies.
I would like to thank the two anonymous peer reviewers for their comments on the first draft of this paper. An earlier version was presented at the XIII conference of the International Association for the Study of Forced Migration (IASFM 13th, July 2011). I am indebted to all the participants who provided me with comments and questions, particularly to Michael Collyer and Katie Walsh. I am also grateful to the British Economic and Social Research Council (ESRC) and to the School of Global Studies, University of Sussex, for funding the research upon which this paper is based. 